\title{
The role of apoptosis in the complex pathogenesis of the most common obstetrics and gynaecology diseases
}

\author{
P. KOVÁCS ${ }^{1,2}$, JÓZSEF GÁBOR JOÓ ${ }^{2,3 *}$ ๑ \\ D. BURIK-HAJAS ${ }^{2}$, J. BÓDIS ${ }^{2,4}$ and L. KORNYA ${ }^{2,5}$
}

\footnotetext{
${ }^{1}$ Clinical Research Units Hungary, Miskolc, Hungary

${ }^{2}$ Doctoral School of Health Sciences, Faculty of Health Sciences, University of Pécs, Pécs, Hungary

${ }^{3}$ First Department of Obstetrics and Gynaecology, Semmelweis University, Budapest, Hungary

${ }^{4}$ Hungarian Academy of Sciences, University of Pécs (MTA-PTE), Human Reproduction Scientific Research Group, University of Pécs, Pécs, Hungary

${ }^{5}$ Central Hospital of Southern Pest, National Institute of Hematology and Infectious Diseases, Budapest, Hungary
}

Received: September 9, 2019 • Accepted: January 7, 2020

Published online: April 23, 2020

(c) 2020 The Author(s)

\begin{abstract}
Purpose: We aimed to assess the etiological role of apoptotic genes Bcl-2 and Bax in the background of major obstetric and gynaecological diseases. Methods: Placental tissue samples were collected from 101 pregnancies with intrauterine growth restriction and 104 pregnancies with premature birth with 140 controll samples from term, eutrophic newborns. In addition, gene expression assessment of the genes Bax and Bcl-2 was performed in 101 uterine leiomyoma tissue samples at our disposal with 110 control cases. Gene expression levels were assessed by PCR method. Results: The expression of the Bcl-2 gene was decreased in placental samples with intrauterine growth restriction. Significant overexpression of the proapoptotic Bax gene was detected in samples from premature infants. Antiapoptotic Bcl-2 gene expression was found to be significantly increased in fibroid tissues. Conclusion: Apoptosis plays a crucial role in the development of the most common OB/GYN conditions. Decrease in the placental expression of the antiapoptotic gene Bcl-2 may upset the balance of programmed cell death.
\end{abstract}

\footnotetext{
* Corresponding author. Clinical Research Units, H-2132 Thököly str. 15, Göd, Hungary. Fax: +36 46798264, E-mail: joogabor@hotmail.com
} 


\section{KEYWORDS}

gene expression, placenta, apoptosis, intrauterine growth restriction, premature birth, uterine leiomyoma, Bcl-2, Bax

\section{ABBREVIATIONS}

IUGR, intrauterine growth restriction, Bcl-2, B cell lymphoma 2, BH, Bcl-2 homologue, BMI, body mass index

\section{INTRODUCTION}

Programmed cell death (apoptosis) plays an important role during the development of the placenta and in the regulation of its ageing during pregnancy [35]. The regulation of programmed cell death is complex; both proapoptotic (stimulating programmed cell death) and antiapoptotic (inhibiting programmed cell death) genes are involved. Members of the Bcl-2 (B cell lymphoma 2) protein family play a prominent role in this complex regulatory system $[8,21$, $25,39]$. Based on structure and function, genes of the Bcl-2 family may also be classified as genes with pro- and anti-apoptotic effect $[4,16,37]$. Genes with antiapoptotic effect include Bcl-2, Bcl$\mathrm{xL}$ (Bcl-extra long), A1, Bcl-w and Boo, whereas the proapoptotic group includes Bax, Bak, and Box genes. Bcl-2 from the antiapoptotic group, and Bax from the proapoptotic group exert the strongest biological effect; accordingly, we simply traced back the regulation and balance of the apoptotic process in the investigated conditions to the establishment of the balance between these two genes, and to the change in their activity $[9,38]$. Several studies have confirmed that the role of apoptosis increases during pregnancy with increasing gestational age, and that this is related to the change in activity of the members of the Bcl-2 gene family [19, 43, 45]. Development and ageing of the placenta are both essential for normal gestation and near-term delivery. Several gestational pathological states have been related to the modified apoptotic activity of trophoblast cells, such as intrauterine growth restriction, premature birth or preeclampsia $[1,11,14,22,23]$.

Changes in apoptotic activity play a role in the development of both benign and malignant tumours. Uterine leiomyomas (benign tumours of the womb originating from smooth muscle) are the most frequent benign tumours in women. Tumour growth is determined by increased cell proliferation and/or decreased intensity of apoptosis. Based on previous data in the literature, it has been suggested that Bcl-2 and Bax gene expression is altered in fibroids compared to normal myometrium [12, 27, 30,47], although this has not yet been confirmed on a larger patient population.

Intrauterine growth restriction (IUGR) is present when foetal weight falls below the 10th percentile of the standard for sex and gestational age [17, 20, 41, 46]. IUGR may result from placental dysfunction, foetal malformations (e.g. chromosomal abnormalities), intrauterine infection (e.g. cytomegalovirus infection, toxoplasmosis), maternal diseases (e.g. kidney diseases, autoimmune diseases) or environmental factors.

Premature birth is present when the pregnancy is terminated by birth before the 37th gestational week. When gestational age cannot be determined accurately, premature birth is defined if the infant's birth weight stays below 2,500 $\mathrm{g}[13,31,42,44]$.

Uterine fibroid is a benign tumour originating from the smooth muscle cells of the womb, which develops mostly in women of child-bearing age, and its incidence increases with 
age $[6,26,28,34]$. The most common symptoms caused by uterine fibroid are irregular bleeding and pelvic pain. It may also lead to obstetric complications like infertility, recurrent abortions and premature delivery, as well as to the compression of other pelvic organs. Although no gene responsible for the development of uterine fibroids not being part of a syndrome has yet been identified, familial accumulation reported in several studies indicates genetic determination of the condition [18].

The aim of our study was to compare Bax (proapoptotic) and Bcl-2 (antiapoptotic) gene expression patterns of placental samples from pregnancies with intrauterine growth restriction or premature birth with those from healthy, eutrophic and mature pregnancies. It was also our aim to assess the expression patterns of the most relevant Bax and Bcl-2 genes depending on the severity of intrauterine growth restriction, and review clinical data that may significantly contribute to the interpretation of gene expression results as well as possible interactions of suspected etiological factors in the background of premature birth. Additionally, our aim was to assess Bcl-2 and Bax gene activity in uterine fibroid tissue in a large number of cases and to analyse it in view of clinical and demographical data.

\section{MATERIALS AND METHODS}

\section{Patients (IUGR)}

During our 1-year study, gene expression results of 101 placenta samples obtained during the birth of infants with intrauterine growth restriction treated at the Semmelweis University 2nd Department of Obstetrics and Gynaecology were compared to the gene expression levels of placental samples obtained during the birth of 140 eutrophic newborns. In addition, basic clinical and demographical data were also analysed. According to one of the study aspects, pregnancies with growth restriction were classified into two groups by severity, depending on the birth weight ranging between $0-5$ th and 5-10th percentile. After excluding intrauterine infections, chromosome disorders, other foetal developmental disorders, maternal malnutrition, multiple pregnancies and placental disorders, functional placental disorder was suggested as the cause of intrauterine growth restriction.

\section{Patients (premature birth)}

During the one-year study, gene expression was investigated in 104 placental samples obtained from pregnancies with premature birth. The diagnostic criteria for premature birth were gestational age younger than 37 th gestational week and/or birth weight below 2,500 g. Cases of intrauterine growth restriction, multiple pregnancy, developmental disorders, maternal anatomical disorder or induced premature birth were excluded from the study. In the investigated cases, premature birth commenced by premature uterine activity and/or premature rupture of the membranes.

\section{Placental sampling, clinical and demographic data collection}

In each case, a tissue sample, approximately $2 \times 2 \times 2 \mathrm{~cm}(8 \mathrm{cc})$ in size, was obtained from the placenta at a distance of approximately $3 \mathrm{~cm}$ from the origin of the umbilical cord. Samples were stored at $-70{ }^{\circ} \mathrm{C}$ until further gene expression assessment. Assessed clinical data: maternal age, 
paternal age, obstetrics history, genetic history, other diseases, mother's birth weight, gestational age at birth, foetal sex, weight gain during pregnancy, change of body mass index (BMI) during pregnancy, carbohydrate metabolism disorder during pregnancy, other obstetrical disease during pregnancy, infant's weight, Apgar score, smoking, and group B Streptococcus screening. Regarding the way of delivery no distinction was made either in placental sampling or in gene expression analysis.

Analyses were performed with the knowledge and consent of expectant mothers in all cases, which was confirmed by their signature (Ethical approval number: TUKEB 114/2009).

\section{Patients (uterine leiomyomas)}

During the one-year study, gene expression results of tissue samples obtained from 101 women undergoing surgery for uterine fibroid at the Semmelweis University 1st Department of Obstetrics and Gynaecology were compared to the gene expression values of tissue samples obtained from 110 women undergoing hysterectomy for causes other than uterine fibroid. The preoperative diagnosis of uterine leiomyoma was established by gynaecological examination and sonography in all cases. The type of surgery was determined according to clinical aspects, patient age, possible further family planning and location, size and number of fibroid(s). The results of gene expression assessment were not sorted according to the type of surgery (transvaginal hysterectomy, transabdominal hysterectomy, fibroid enucleation). During the interpretation of gene expression results only the cases where the diagnosis of uterine fibroid was also confirmed by postoperative histological evaluation were included. Only those cases were assigned as controls where the indication for hysterectomy was other than uterine fibroid or malignant tumour. The fulfilment of these criteria was confirmed by histological evaluation in all cases.

\section{Leiomyoma tissue sampling and clinical and demographic data collection}

In the cases of myoma enucleation, tissue samples $1 \times 1 \times 1 \mathrm{~cm}(1 \mathrm{cc})$ in size were obtained from the removed tumour when possible. Samples were stored at $-70{ }^{\circ} \mathrm{C}$ until further gene expression assessment. When multiple fibroids were removed, samples were obtained from each of the resected tumours. In these cases, the average of the gene expression values of the individual fibroids was calculated and considered as one value. For hysterectomy, the tissue sample was obtained from the fibroid when possible; or if not, sampling was performed in the region of the fundus of the removed womb at a volume of 6-8 cc. For control cases, a tissue sample $2 \times 2 \times 2 \mathrm{~cm}$ in size was removed from the region of the fundus of the uterus.

Assessed clinical data: age, family history of uterine fibroids, time of the first period, number of pregnancies, number and way of deliveries, (total) length of lactation period(s) after pregnancy (pregnancies), unsuccessful pregnancies (spontaneous abortion, missed abortion, artificial abortion), oral contraception, preoperative sonographic result, number, size and location of uterine fibroids, type of the surgery, and the results of histological evaluation. For pregnancies, the total amount of time spent being pregnant was used, given in weeks. An average of 37 gestational weeks per pregnancy was used for our analysis. (The time of pregnancies ending in termination by spontaneous or artificial abortion, in view of their shortness, was not taken into consideration). 


\section{Gene expression assessment (IUGR, premature birth and uterine fibroid)}

The total amount of RNA present in the placental and fibroid samples was extracted with the Quick RNA Micropep Kit (Zymo Research), then RNA concentration was measured by the NanoDrop spectrophotometer (NanoDrop). Reverse transcription (RT) was performed in a final volume of $20 \mu \mathrm{L}$ : using $5 \mu \mathrm{g}$ of total RNA, 75 pmol of random hexamer primer, $10 \mathrm{mM}$ of dNTP (Invitrogen), $20 \mathrm{U}$ M-MuLV Reverse Transciptase enzyme (MBI Fermentas) and $1 \times$ buffer (MBI Fermentas). The reaction mixture was incubated at $42{ }^{\circ} \mathrm{C}$ for $2 \mathrm{~h}$, then the enzyme was inactivated at $70{ }^{\circ} \mathrm{C}$ for $15 \mathrm{~min}$.

The reverse transcription reaction mixture was diluted threefold with nuclease-free water. For real-time PCR, $1 \mu \mathrm{L}$ of diluted cDNA (the equivalent of $\sim 15$ ng RNA) and $1 \times$ SYBR Green Master Mix (Applied Biosystems) were used. Primers were designed using the Primer Express Software (Applied Biosystems) (primer sequences are presented in Table 1). Real-time PCR reaction was performed with $1 \mu \mathrm{L}$ cDNA, 1 pmol, gene-specific Forward and Reverse primers and $1 \times$ SYBR Green PCR Master mix in a final volume of $20 \mu \mathrm{L}$. All real-time PCR reactions were carried out with MX3000 Real-time PCR (Stratagen) equipment according to the following protocol: 40 cycles, denaturation at $95{ }^{\circ} \mathrm{C}$ for $15 \mathrm{~s}$, primer-annealing, chain lengthening and detecting at $60{ }^{\circ} \mathrm{C}$ for $60 \mathrm{~s}$. The relative expression of each gene was normalised for the human $\beta$-actin gene.

\section{Statistical analysis}

The Stratagen MX3000 real time PCR software (Stratagen) was used to calculate gene expression values. Threshold cycle value $(\mathrm{Ct})$ is defined as the reaction time (real-time PCR cycle time) by which the evaluating software detects a fluorescent signal that unequivocally deviates from the baseline signal. The delta $C t$ value $(\Delta C t)$ demonstrates the difference between the $C t$ value of the target gene measured in the assessed sample and that of the internal control gene $\left(\Delta C t=C t_{\text {assessed gene }}-C t_{\text {internal control gene }}\right)$. The $\alpha$-value characterises the relative difference of target genes between two different samples $\left(\Delta C t_{\text {sample } 1}-\Delta C t_{\text {sample } 2}\right)$. The natural logarithm of the $2^{\dot{\alpha}}$ value shows how the relative amount of the target gene RNA compares between two samples. The UCL (upper confidence limit) and the LCL (lower confidence limit) refer to the highest and lowest relative differences between assessed samples, respectively.

A two-sample $t$-test was used to assess gene expression results (confidence interval 95\%). The degree of freedom was determined by Welch-Satterthwaite approximation. Gene expression

Table 1. Primers and sequences used for real-time PCR reactions in the gene expression assessments for IUGR, premature birth and leiomyoma uterine

\begin{tabular}{llc}
\hline Name and ID of gene & Forward primer & Reverse primer \\
\hline Bcl-2 (NM_000633) & 5'-ATGTGTGTGGAGAGCGTCAACC-3' $^{\prime}$ & 5'-TGAGCAGAGTCTTC $^{\prime}$ AGAGACAGCC-3' \\
Bax (NM_004324) & 5'-CCTTTTCTACTTTGCCAGCAAAC-3' $^{\prime}$ & $5^{\prime}$-GAGGCCGTCCCA \\
$\beta$-Actin (M10277) & $5^{\prime}$-GGCACCCAGCACAATGAAG-3' & ACCAC-3' \\
& & $5^{\prime}$-GCCGATCCACACG \\
\end{tabular}


values were classified into the following groups: (1) overactive gene: if the Ln value of the calculated data $>1, P<0.05$; (2) underactivity: if the Ln value of the calculated data $<-1, P<0.05$; (3) unchanged activity: if the Ln value of the calculated data $<1,>-1, P<0.05$. GraphPad Prism 3.0 (GraphPad Software Inc, La Jolla, CA, USA) software was used for all statistical evaluations.

To analyse demographic and clinical data, we created models with mathematical statistical tools, using the SPSS software package. As multidimensional process we applied logistic regression (due to the dichotomous dependent variables), analysis of variance (ANOVA) and linear regression. Correlations were considered significant when $P<0.05$.

\section{RESULTS}

\section{Clinical data (IUGR)}

Male:female ratio was 0.58 (64 boys; 37 girls) and 1.09 (boys: 73; girls: 67) in the intrauterine growth restriction group and in the eutrophic control group, respectively $(P<0.05)$. The median age of expectant mothers did not differ significantly $(30.82 \pm 4.34$ years/IUGR/vs $31.45 \pm 3.12$ years/eutrophic/; $P>0.05)$, whereas significant differences were observed regarding weight gain during pregnancy (14.8 kg/eutrophic/vs $10.9 \mathrm{~kg} / \mathrm{IUGR} /)$ and change in body mass index $(+5.3 /$ eutrophic/vs $4.1 / \mathrm{IUGR} /)$ of pregnant women $(P<0.05)$.

Regarding the birth weight of expectant mothers, our data confirmed that the birth weight (median: 2,830 g) of women delivering infants with birth weight between $0-5$ th percentile was significantly lower than those delivering infants with birth weight between 5 and 10th percentile (median: 3,120 g) $(P<0.05)$.

\section{Clinical data (premature birth)}

Boy:girl ratio was 0.89 (49 boys; 55 girls) and 1.09 (73 boys; 67 girls) among premature infants and in the control group, respectively $(P>0.05)$. Median age of women giving birth prematurely did not show any significant difference compared to the control group $(30.7 \pm 5.20$ years/ premature birth/vs $31.4 \pm 3.12$ years/mature birth/) $(P>0.05)$.

Prenatal weight gains of pregnant women delivering mature and premature infants, that were compared during the study, showed a significant difference in accordance with the shorter gestational period preceding premature births $(11.6 \pm 4.6 \mathrm{~kg} / \mathrm{premature} \mathrm{birth/vs} 14.7 \pm 2.6 \mathrm{~kg} /$ mature birth/) $(P<0.05)$.

The rate of regular smokers with pregnancies terminating in premature birth was $26.9 \%$ (28/ 104) compared to $7.1 \%$ in the mature control group $(10 / 140)(P<0.05)$.

Premature birth commenced with premature rupture of the membranes in $70.2 \%$ of cases $(73 / 104)$ and spontaneous uterine activity in $29.8 \%$ of cases $(31 / 104)$.

\section{Clinical data (uterine leiomyoma)}

Patients treated for uterine leiomyoma were significantly younger (median age) than patients in the control group $(47.5 \pm 12.1$ years vs $54.7 \pm 10.2$ years; $P<0.05)$.

Regarding the median length of total time spent pregnant in weeks, our data showed that women with leiomyomas spent a significantly shorter time in pregnancy (105.1 \pm 8.2 weeks) than patients in the control group $(127.2 \pm 9.1$ week $)(P<0.05)$. 
Table 2. The incidence of the most common symptoms of leiomyoma uterine in the myoma and control group

\begin{tabular}{lllll}
\hline & \multicolumn{2}{c}{ Myoma cases } & \multicolumn{2}{c}{ Control cases } \\
\cline { 2 - 5 } Symptoms & $n$ & $\%$ & $n$ & $\%$ \\
\hline $\begin{array}{c}\text { Abdominal pain: negative; bleeding } \\
\text { disorder: negative } \\
\text { Abdominal pain: negative; bleeding } \\
\quad \text { disorder: positive }\end{array}$ & 26 & 25.7 & 56 & 51.1 \\
$\begin{array}{c}\text { Abdominal pain: positive; bleeding } \\
\text { disorder: negative }\end{array}$ & 12 & 12.2 & 16 & 14.4 \\
$\begin{array}{c}\text { Abdominal pain: positive; bleeding } \\
\text { disorder: positive }\end{array}$ & 35 & 35.1 & 17 & 15.3 \\
Total & $\mathbf{1 0 1}$ & 100 & $\mathbf{1 1 0}$ & 100 \\
\hline
\end{tabular}

Nulliparity was significantly more frequent among women with fibroids $(32 / 101 ; 31.7 \%)$ than in the control group $(6 / 110 ; 5.5 \%)(P<0.05)$.

Lactation period following pregnancy was, understandably, significantly shorter than in the control group $(2.4 \pm 1.2$ months vs $5.1 \pm 2.2$ months; $P<0.05)$.

The prevalence of the two most common symptoms of uterine leiomyomas (bleeding disorder, lower abdominal pain) together, as well as that of the bleeding disorder on its own was significantly higher $(P<0.05)$ in the group of patients with uterine fibroids than among control cases (Table 2).

Of the 101 leiomyoma cases, 40 enucleations (39.6\%) and 61 hysterectomies (60.4\%) were performed.

\section{Gene expression assessment}

The expression of the proapoptotic Bax gene did not show any significant differences in the samples from pregnancies with IUGR, whereas the antiapoptotic Bcl-2 gene showed a significant

Table 3. Bax- and Bcl-2 gene expression activities in the placenta samples with intrauterine growth restriction compared to control samples from eutrophic pregnancies

\begin{tabular}{lcccccccc}
\hline $\begin{array}{l}\text { Name } \\
\text { of gene }\end{array}$ & $\begin{array}{c}\Delta C t_{\text {eutrophic }} \\
\pm \mathrm{SE}^{(\mathrm{I} .)}\end{array}$ & $\begin{array}{c}\Delta C t_{\mathrm{IUGR}} \pm \\
\mathrm{SE}^{(\mathrm{II} .)}\end{array}$ & $\begin{array}{c}\alpha \text { value } \pm \\
\mathrm{SE}(\alpha)^{(\mathrm{III} .)}\end{array}$ & $\begin{array}{c}\mathrm{Ln} \\
2^{\alpha}\end{array}$ & $\mathrm{LCL}$ & $\mathrm{UCL}$ & $P$ & $\begin{array}{c}\text { Gene } \\
\text { expression } \\
\text { changes }\end{array}$ \\
\hline $\mathrm{Bax}$ & $3.18 \pm 0.82$ & $4.04 \pm 0.67$ & $-0.86 \pm 0.5$ & -0.59 & 0.43 & -1.21 & 0.06 & $\begin{array}{c}\text { Not changed in } \\
\text { function }\end{array}$ \\
$\mathrm{Bcl}-2$ & $3.18 \pm 0.82$ & $6.32 \pm 0.86$ & $-3.14 \pm 0.81$ & -2.17 & 0.85 & -3.79 & 0.04 & Underactivity \\
\hline
\end{tabular}

UCL: upper confidence limit.

LCL: lower confidence limit.

Significant difference: $P<0.05$.

(I.) $\Delta C t_{\text {eutrophic }}=C t_{\text {assesed gene }}-C t_{\beta \text {-actin }} \mathrm{n}_{\text {IUGR }}=101$.

(II.) $\Delta C t_{\mathrm{IUGR}}=C t_{\text {assesed gene }}-C t_{\beta \text {-actin }} \mathrm{n}_{\text {eutrophic }}=140$.

(III.) $\alpha=\Delta C t_{\text {eutrophic }}-\Delta C t_{\text {IUGR. }}$. 
Table 4. Bax and Bcl-2 gene expression of placental samples from foetuses with severe intrauterine growth restriction classified into the $0-5$ th percentile weight range, compared to similar parameters of foetuses with milder intrauterine growth restriction of 5-10th percentile

\begin{tabular}{lcccccc}
\hline $\begin{array}{l}\text { Name of } \\
\text { gene }\end{array}$ & $\Delta C t_{\mathrm{A}} \pm \mathrm{SE}$ & $\Delta C t_{\mathrm{B}} \pm \mathrm{SE}$ & $\alpha$ value $\pm \mathrm{SE}(\alpha)$ & $\operatorname{Ln} 2^{\alpha}$ & $P$ & $\begin{array}{c}\text { Gene expression } \\
\text { changes }\end{array}$ \\
\hline $\mathrm{Bax}$ & $4.32 \pm 0.46$ & $3.76 \pm 0.3$ & $0.56 \pm 0.28$ & 0.38 & 0.06 & $\begin{array}{c}\text { Not changed in function } \\
\text { Bcl-2 }\end{array}$ \\
\hline
\end{tabular}

A: $5-10$ percentile IUGR placental sample; $n_{\text {total }}=101\left(n_{\mathrm{A}}=60, n_{\mathrm{B}}=41\right)$.

B: $0-5$ percentile IUGR placental sample.

$\Delta C t_{\mathrm{A}}=C t_{\text {assesed gene }}-C t_{\beta \text {-actin; }}$

$\Delta C t_{\mathrm{B}}=C t_{\text {assesed gene }}-C t_{\beta \text {-actin }}$

$\alpha=\Delta C t_{\mathrm{A}}-\Delta C t_{\mathrm{B}}$

Significant difference: $P<0.05$.

underactivity in the placenta samples with IUGR compared to control samples from eutrophic pregnancies $(P<0.05)$ (Table 3$)$.

No significant differences could be shown in Bax and Bcl-2 gene expression of placental samples from foetuses with severe IUGR classified into the $0-5$ th percentile weight range, compared to similar parameters of foetuses with milder intrauterine growth restriction of 5-10th percentile (Table 4).

Regarding gene expression activity of placenta samples from premature infants, a significant overexpression of the proapoptotic Bax gene could be detected compared to gene expression activity in the mature control group $(P<0.05)$, whereas the antiapoptotic $\mathrm{Bcl}-2$ gene did not show any significant change in activity (Table 5$)$.

Depending on gestational age, placental Bax and Bcl-2 gene expression values compared to the placental values from term births were detected as follows: no significant difference was present in the activity of antiapoptotic Bcl-2 gene in premature births at weeks 24-28, 28-32 and

Table 5. Bax and $\mathrm{Bcl}-2$ gene expression activities of placenta samples from premature infants compared to gene expression activity in the mature control group

\begin{tabular}{lcccccccc}
\hline $\begin{array}{l}\text { Name } \\
\text { of gene }\end{array}$ & $\begin{array}{c}\Delta C t_{\text {eutrophic }} \\
\pm \mathrm{SE}^{(\mathrm{II})}\end{array}$ & $\begin{array}{c}\Delta C t_{\text {premature }} \\
\pm \mathrm{SE}^{(\mathrm{II} .)}\end{array}$ & $\begin{array}{c}\alpha \text { value } \pm \\
\mathrm{SE}(\alpha)^{(\mathrm{III} .)}\end{array}$ & $\begin{array}{c}\text { Ln } \\
2^{\alpha}\end{array}$ & LCL & $\mathrm{UCL}$ & $P$ & $\begin{array}{c}\text { Gene } \\
\text { expression } \\
\text { changes }\end{array}$ \\
\hline $\mathrm{Bcl}-2$ & $2.76 \pm 0.48$ & $2.53 \pm 0.7$ & $-0.23 \pm 0.6$ & -0.15 & -1.12 & 0.91 & 0.07 & $\begin{array}{c}\text { Not changed } \\
\text { in function }\end{array}$ \\
$\mathrm{Bax}$ & $2.97 \pm 0.8$ & $1.02 \pm 0.65$ & $1.95 \pm 0.72$ & 1.35 & 0.82 & 2.13 & 0.04 & Overactivity \\
\hline
\end{tabular}

UCL: upper confidence limit.

LCL: lower confidence limit.

Significant difference: $P<0.05$.

(I.) $\Delta C t_{\text {eutrophic }}=C t_{\text {assesed gene }}-C t_{\beta \text {-actin }} ; n_{\text {premature }}=104 ; n_{\text {eutrophic }}=140$.

(II.) $\Delta C t_{\text {premature }}=C t_{\text {assesed gene }}-C t_{\beta \text {-actin; }}$

(III.) $\alpha=\Delta C t_{\text {eutrophic }}-\Delta C t_{\text {premature. }}$ 
Table 6. Bax and Bcl-2 gene expression activities of placenta samples from premature infants compared to gene expression activity in the mature control group based on gestational age

\begin{tabular}{rccccc}
\hline$n$ & Gestational age & Bax Ln $2^{\alpha}$ & $P$ & Bcl-2 Ln $2^{\alpha}$ & $P$ \\
\hline 15 & Week 24-28. & 0.87 & 0.03 & 0.03 & 0.05 \\
25 & Week 28-32. & 1.56 & 0.06 & -0.58 & 0.06 \\
64 & Week 32-36. & 1.41 & 0.04 & 0.4 & 0.06 \\
\hline
\end{tabular}

$n_{\text {premature }}=104$.

Significant difference: $P<0.05$.

32-36, whereas the proapoptotic Bax gene demonstrated significant overexpression in premature births at weeks $28-32$ and 32-36, and no change of activity in premature births at weeks 24-28, compared to similar values of control samples (Table 6).

The expression of the antiapoptotic Bcl-2 gene in uterine fibroid tissue samples was shown to be significantly increased $(P<0.05)$ compared to expression values of samples in the control group, whereas the expression of the proapoptotic Bax gene did not show any significant difference (Table 7).

When comparing Bcl-2 and Bax gene expression in cases with negative and positive family histories of uterine fibroids, significant difference in gene expression activity was not identified.

Significant Bax gene expression difference was not detected according to the number of fibroids compared to physiological myometrium; however, Bcl-2 gene activity showed a significant correlation with the number of tumours $(P<0.05)$, i.e. overexpression was found to be more pronounced in cases of multiple fibroids (Table 8 ).

When assessing Bcl-2 and Bax gene expression activity in relation to the length of lactation period following pregnancies prior to the development of uterine fibroids, no significant changes were detected compared to the gene activity in women who had not lactated previously, whereas Bcl-2 gene activity was shown to be higher in the case of a shorter lactation period.

Table 7. Bax- and Bcl-2 gene expression activity in uterine fibroid tissue compared to the normal myometrium control group

\begin{tabular}{|c|c|c|c|c|c|c|c|c|}
\hline $\begin{array}{l}\text { Name } \\
\text { of gene }\end{array}$ & $\underset{\mathrm{SE}^{(\mathrm{II})}}{\Delta C t_{\text {normal }}} \pm$ & $\underset{\mathrm{SE}^{(\mathrm{III} .)}}{\Delta C t_{\text {fibroid }} \pm}$ & $\begin{array}{l}\alpha \text { value } \pm \\
\operatorname{SE}(\alpha)^{(\mathrm{IIII} .)}\end{array}$ & $\begin{array}{l}\operatorname{Ln} \\
2^{\alpha}\end{array}$ & LCL & UCL & $P$ & $\begin{array}{c}\text { Gene } \\
\text { expression } \\
\text { changes }\end{array}$ \\
\hline $\mathrm{Bcl}-2$ & $8.24 \pm 0.83$ & $6.03 \pm 0.82$ & $2.21 \pm 0.75$ & 1.53 & 0.2 & 3.24 & 0.04 & Overactivity \\
\hline Bax & $12.72 \pm 1.01$ & $13.93 \pm 0.9$ & $-1.21 \pm 0.95$ & -0.83 & -1.24 & 1.77 & 0.06 & $\begin{array}{l}\text { Not changed } \\
\text { in function }\end{array}$ \\
\hline
\end{tabular}

UCL: upper confidence limit.

LCL: lower confidence limit.

Significant difference: $P<0.05$.

(I.) $\Delta C t_{\text {lnormal }}=C t_{\text {assesed gene }}-C t_{\beta \text {-actine }}$.

(II.) $\Delta C t_{\text {fibroid }}=C t_{\text {assesed gene }}-C t_{\beta \text {-actine }}$.

(III.) $\alpha=\Delta C t_{\text {normal }}-\Delta C t_{\text {fibroid }}$. 
Table 8. The Bcl-2 and Bax gene expression activity in relation to the number of fibroids compared to physiological myometrium

\begin{tabular}{lcrcc}
\hline Number of fibroids & $\alpha$ value $\pm \operatorname{SE}(\alpha)$ & Ln $2^{\alpha}$ & $P$ & $\begin{array}{c}\text { Gene expression } \\
\text { changes }\end{array}$ \\
\hline Bcl-21 $(n=53)$ & $2.01 \pm 0.69$ & 1.13 & 0.04 & Overactivity \\
Bcl-22 $(n=13)$ & $1.89 \pm 0.8$ & 1.37 & 0.04 & Overactivity \\
Bcl-2more than 2 $(n=23)$ & $2.3 \pm 0.74$ & 1.69 & 0.04 & Overactivity \\
Bax $(n=53)$ & $-0.65 \pm 0.98$ & -0.45 & 0.06 & Not changed in function \\
Bax2 $(n=13)$ & $0.02 \pm 0.8$ & 0.01 & 0.05 & Not changed in function \\
Baxmore than 2 $(n=23)$ & $-0.42 \pm 0.64$ & -0.29 & 0.05 & Not changed in function \\
\hline
\end{tabular}

$\alpha=\Delta C t_{\text {normal }}-\Delta C t_{\text {fibroid. }}$

Control gene: $\beta$-aktin.

\section{DISCUSSION}

The clinical results obtained are rather referential and serve as adequate clinical characterisation of the assessed patient population, as - based on the low number of cases - it has no statistical value.

Among environmental factors, the most important etiological factor of premature delivery was shown to be smoking during pregnancy. Smoking decreases the amount of available oxygen needed for intrauterine foetal development, and also decreases the level of serum IGF-1. The latter may also play a role in the imbalance of energy intake - oxygenation axis which is essential for the intrauterine health of the foetus [10].

Confirming ample literature data, our research also showed an inverse ratio between the number of pregnancies and incidence of uterine fibroids [36].

Regarding lactation and incidence of uterine fibroids, our results have shown that women treated for uterine fibroid had been pregnant fewer times and for shorter periods of time than patients in the control group; therefore, the rate of non-lactating women in the group of uterine fibroids was found to be significantly higher (27.4\% vs $3 \%)$. Prolactin, the hormone regulating the lactation period, stimulates rather than inhibits the development of fibroids [33].

Embedding of placental tissue into the uterine wall is an aggressive process from a histological aspect, which brings the growth of malignant tumours into mind to some degree. Genes regulating apoptosis can be identified during the entire gestational period [24]. Although some studies reported an overexpression of the antiapoptotic Bcl-2 gene at the end of pregnancy [5], in the case of eutrophic intrauterine foetal development, significantly more data are available confirming underactivity $[2,32]$. The expression of the proapoptotic Bax gene during physiological pregnancy probably increases near to the end of pregnancy, or at least that is being suggested by literature data $[19,45]$.

Based on assessments on placenta samples from pregnancies with intrauterine growth restriction, Barrio and his group confirmed decreased expression of the antiapoptotic Bcl-2 gene, whereas Agata and colleagues attributed the apoptotic imbalance to the overexpression of the proapoptotic Bax gene, and found placental Bcl-2 gene expression to be unchanged [2, 25]. Our study data match the results of Barrio et al., i.e. we could confirm for a large number of cases that in case of intrauterine growth restriction, a decrease in placental Bcl-2 gene activity can be observed [29] resulting in a less dominating presence of apoptosis-inhibiting mechanisms [2]. In pregnancies with intrauterine growth restriction, Agata et al. found an increase in placental Bax gene expression activity which stimulates the process of programmed cell death [25], and this 
was also confirmed by Heazell et al.'s studies [21]. Unlike these previous results, our analysis did not show any difference in placental Bax gene activity in cases of intrauterine growth restriction compared to the control group.

De Falco et al. recommends the simultaneous assessment of Bcl-2 and Bax gene expression activities during physiological pregnancies for a flexible interpretation of the phenomenon of apoptosis [9]. This model allows simultaneous review of the changes in the activity of the most important proapoptotic and antiapoptotic genes, also highlighting the fact that one cannot interpreted without the other. Due to the placental functional disorders present in pathological pregnancies (such as IUGR) this model is even more useful, as there is a higher chance that pathological conditions are associated with changes in the regulation of programmed cell death. Based on the above model, our study results match the hypothesis suggesting changes in the activity of genes that exert stimulating and inhibitory effect on the process of apoptosis in the case of IUGR. However, gene expression observed in our study confirmed a decrease in antiapoptotic effects in the background of IUGR rather than an increase in gene activity stimulating programmed cell death.

The expression pattern of the assessed genes (Bcl-2, Bax) that influence programmed cell death did not show any difference in relation to the degree of underdevelopment of the foetus with intrauterine growth restriction [3].

Several studies investigated the role of apoptosis in the development of the premature rupture of the membranes, which is the most common cause for premature birth [40]. Fortunato et al. detected a definitive increase in Bax and a decrease in Bcl-2 gene activity in placental samples from premature births [15]. We also observed an undeniable increase in the activity of the proapoptotic Bax gene in placenta samples from premature births; however, we did not detect any changes in gene expression regarding the antiapoptotic $\mathrm{Bcl}-2$ gene; i.e. in the process of apoptosis contributing to the initiation of premature birth, the overexpression of the activating Bax gene might play the primary role, and the underactivity of the inhibitory Bcl-2 gene is less important.

Gestational age at the time of premature birth is a relevant aspect regarding the placental activity of the proapoptotic Bax gene, as it shows an increase in activity in premature births after the 28th gestational week, whereas no change at all was identified in the activity of the Bcl-2 gene. Apoptosis might play a less important part in premature births between gestational weeks 24-28 than in cases following the 28th gestational week.

In both benign and malignant tumour growth, an imbalance between cell division and death can always be observed. According to our results, the Bcl-2 gene is overexpressed in uterine leiomyomas compared to the gene expression pattern in the normal myometrium, indicating that the imbalance of apoptosis playing a role in the development of fibroids may be attributed to the overactivity of an antiapoptotic gene (Bcl-2), while the proapoptotic Bax gene is functioning normally [7].

The gene expression analysis of apoptosis in case of the most common OB/GYN diseases may contribute to successful research for the efficient prediction of IUGR, premature birth as well as uterine fibroids in the future.

Conflict of interest: The authors report no conflict of interest.

\section{ACKNOWLEDGEMENTS}

I would like to acknowledge the significant contribution of my colleagues at the 1st and 2nd Department of Obstetrics and Gynecology, Semmelweis University in performing this study. 


\section{REFERENCES}

1. Allaire AD, Ballenger KA, Wells SR, McMahon MJ, Lessey BA. Placental apoptosis in preeclampsia. Obstet Gynecol 2000; 96: 271-6.

2. Barrio E, Calvo MT, Romo A, Alvarez R, Gutierrez JI, Naval J, et al. Intrauterine growth retardation: study of placental apoptosis. J Pediatr Endocrinol Metab 2004; 17(Suppl. 3): 451-6.

3. Börzsönyi B, Demendi C, Rigó J Jr, Szentpéteri I, Rab A, Joó JG. The regulation of apoptosis in intrauterine growth restriction: a study of $\mathrm{Bcl}-2$ and Bax gene expression in human placenta. J Matern Fetal Neonatal Med 2013; 26: 347-50.

4. Budd RC. Activation-induced cell death. Curr Opin Immunol 2001; 13: 356-62.

5. Cirelli N, Moens A, Lebrun P, Gueuning C, Delogne-Desnoeck J, Vanbellinghen AM, et al. Apoptosis in human term placenta is not increased during labor but can be massively induced in vitro. Biol Reprod 1999; 61: 458-63.

6. Cramer SF, Patel A. The frequency of uterine leiomyomas. Am J Clin Pathol 1990; 94: 435-8.

7. Csatlós E, Máté S, Laky M, Rigó J Jr, Joó JG. Role of Apoptosis in the Development of Uterine Leiomyoma: analysis of expression patterns of Bcl-2 and Bax in human Leiomyoma tissue with clinical correlations. Int J Gynecol Pathol 2015; 34: 334-9.

8. Daher S, Guimaraes AJ, Mattar R, Ishigai MM, Barreiro EG, Bevilacqua E. Bcl-2 and Bax expressions in preterm, term and post-term placentas. Am J Reprod Immunol 2008; 60: 172-8.

9. De Falco M, De Luca L, Acanfora F, Cavallotti I, Cottone G, Laforgia V, et al. Alteration of the Bcl-2:Bax ratio in the placenta as pregnancy proceeds. Histochem J 2001; 33: 421-5.

10. Demendi C, Börzsönyi B, Végh V, Nagy ZB, Rigó J Jr, Pajor A, et al. Gene expression patterns of the Bcl-2 and Bax genes in preterm birth. Acta Obstet Gynecol Scand 2012; 91: 1212-7.

11. Diplas AI, Lambertini L, Lee MJ, Sperling R, Lee YL, Wetmur J, et al. Differential expression of imprinted genes in normal and IUGR human placentas. Epigenetics 2009; 4: 235-40.

12. Dixon D, He H, Haseman JK. Immunohistochemical localization of growth factors and their receptors in uterine leiomyomas and matched myometrium. Environ Health Perspect 2000; 108(Suppl. 5): 795-802.

13. Ehn NL, Cooper ME, Orr K, Shi M, Johnson MK, Caprau D, et al. Evaluation of fetal and maternal genetic variation in the progesterone receptor gene for contributions to preterm birth. Pediatr Res 2007; 62: 630-5.

14. Endo H, Okamoto A, Yamada K, Nikaido T, Tanaka T. Frequent apoptosis in placental villi from pregnancies complicated with intrauterine growth restriction and without maternal symptoms. Int J Mol Med 2005; 16: 79-84.

15. Fortunato SJ, Menon R, Bryant C, Lombardi SJ. Programmed cell death (apoptosis) as a possible pathway to metalloproteinase activation and fetal membrane degradation in premature rupture of membranes. Am J Obstet Gynecol 2000; 182: 1468-76.

16. Germain M, Shore GC. Cellular distribution of Bcl-2 family proteins. Sci STKE 2003; 2003 : pe10.

17. Gluckman PD, Harding JE. The physiology and pathophysiology of intrauterine growth retardation. Horm Res 1997; 48(Suppl. 1): 11-6.

18. Gross KL, Panhuysen CI, Kleinman MS, Goldhammer H, Jones ES, Nassery N, et al. Involvement of fumarate hydratase in nonsyndromic uterine leiomyomas: genetic linkage analysis and FISH studies. Genes Chromosomes Cancer 2004; 41: 183-90.

19. Halperin R, Peller S, Rotschild M, Bukovsky I, Schneider D. Placental apoptosis in normal and abnormal pregnancies. Gynecol Obstet Invest 2000; 50: 84-7.

20. Hamilton BE, Martin JA, Ventura SJ. Births: preliminary data for 2005. Natl Vital Stat Rep 2006; 55: 1-18. 
21. Heazell AE, Sharp AN, Baker PN, Crocker IP. Intra-uterine growth restriction is associated with increased apoptosis and altered expression of proteins in the p53 pathway in villous trophoblast. Apoptosis 2011; 16: $135-44$.

22. Hu R, Zhou S, Li X. Altered Bcl-2 and Bax expression is associated with cultured first trimester human cytotrophoblasts apoptosis induced by hypoxia. Life Sci 2006; 79: 351-5.

23. Hung TH, Chen SF, Liou JD, Hsu JJ, Li MJ, Yeh YL, et al. Bax, Bak and mitochondrial oxidants are involved in hypoxia-reoxygenation-induced apoptosis in human placenta. Placenta 2008; 29: 565-83.

24. Ishihara N, Matsuo H, Murakoshi H, Laoag-Fernandez J, Samoto T, Maruo T. Changes in proliferative potential, apoptosis and Bcl-2 protein expression in cytotrophoblasts and syncytiotrophoblast in human placenta over the course of pregnancy. Endocr J 2000; 47: 317-27.

25. Karowicz-Bilińska A, Szczerba A, Kowalska-Koprek U, Nawrocka-Kunecka A, Bartosz G. Expression of caspase-3, Bax nad Bcl-2 in placentas from pregnancies complicated by treated and non-treated fetal growth restriction. Ginekol Pol 2009; 80: 652-6.

26. Khurana KK, Singh SB, Tatum AH, Schulz V, Badawy SZ. Maintenance of increased Bcl-2 expression in uterine leiomyomas after GnRH agonist therapy. J Reprod Med 1999; 44: 487-92.

27. Leiser AL, Anderson SE, Nonaka D, Chuai S, Olshen AB, Chi DS, et al. Apoptotic and cell cycle regulatory markers in uterine leiomyosarcoma. Gynecol Oncol 2006; 101: 86-91.

28. Marshall LM, Spiegelman D, Barbieri RL, Goldman MB, Manson JE, Colditz GA, et al. Variation in the incidence of uterine leiomyoma among premenopausal women by age and race. Obstet Gynecol 1997; 90: 967-73.

29. Martel KM, Ko AC, Christman GM, Stribley JM. Apoptosis in human uterine leiomyomas. Semin Reprod Med 2004; 22: 91-103.

30. Matsuo H, Maruo T, Samoto T. Increased expression of Bcl-2 protein in human uterine leiomyoma and its up-regulation by progesterone. J Clin Endocrinol Metab 1997; 82: 293-9.

31. McCormick MC. The contribution of low birth weight to infant mortality and childhood morbidity. N Engl J Med 1985; 312: 82-90.

32. McLaren J, Taylor DJ, Bell SC. Increased incidence of apoptosis in non-labour-affected cytotrophoblast cells in term fetal membranes overlying the cervix. Hum Reprod 1999; 14: 2895-900.

33. Nohara A, Ohmichi M, Koike K, Jikihara H, Kimura A, Masuhara K, et al. Prolactin stimulates mitogenactivated protein kinase in human leiomyoma cells. Biochem Biophys Res Commun 1997; 238: 473-7.

34. Okolo S. Incidence, aetiology and epidemiology of uterine fibroids. Best Pract Res Clin Obstet Gynaecol 2008; 22: $571-88$.

35. Ola MS, Nawaz M, Ahsan H. Role of Bcl-2 family proteins and caspases in the regulation of apoptosis. Mol Cell Biochem 2011; 351: 41-58.

36. Parazzini F, Negri E, La Vecchia C, Chatenoud L, Ricci E, Guarnerio P. Reproductive factors and risk of uterine fibroids. Epidemiology 1996; 7: 440-2.

37. Petros AM, Olejniczak ET, Fesik SW. Structural biology of the Bcl-2 family of proteins. Biochim Biophys Acta 2004; 1644: 83-94.

38. Ratts VS, Tao XJ, Webster CB, Swanson PE, Smith SD, Brownbill P, et al. Expression of BCL-2, BAX and BAK in the trophoblast layer of the term human placenta: a unique model of apoptosis within a syncytium. Placenta 2000; 21: 361-6.

39. Ray J, Jurisicova A, Caniggia I. IFPA Trophoblast Research Award Lecture: the dynamic role of Bcl-2 family members in trophoblast cell fate. Placenta 2009; 30(Suppl. A): S96-100.

40. Sagol S, Sagol O, Ozkal S, Asena U. Role of apoptosis, bcl-2 and bax protein expression in premature rupture of fetal membranes. J Reprod Med 2002; 47: 809-15. 
41. Sheikh S, Satoskar P, Bhartiya D. Expression of insulin-like growth factor-I and placental growth hormone mRNA in placentae: a comparison between normal and intrauterine growth retardation pregnancies. Mol Hum Reprod 2001; 7: 287-92.

42. Slattery MM, Morrison JJ. Preterm delivery. Lancet 2002; 360: 1489-97.

43. Smith SC, Baker PN, Symonds EM. Placental apoptosis in normal human pregnancy. Am J Obstet Gynecol 1997; 177: 57-65.

44. Steffen KM, Cooper ME, Shi M, Caprau D, Simhan HN, Dagle JM, et al. Maternal and fetal variation in genes of cholesterol metabolism is associated with preterm delivery. J Perinatol 2007; 27: 672-80.

45. Straszewski-Chavez SL, Abrahams VM, Mor G. The role of apoptosis in the regulation of trophoblast survival and differentiation during pregnancy. Endocr Rev 2005; 26: 877-97.

46. Wollmann HA. Intrauterine growth restriction: definition and etiology. Horm Res 1998; 49(Suppl. 2): 1-6.

47. Wu X, Blanck A, Olovsson M, Henriksen R, Lindblom B. Expression of Bcl-2, Bcl-x, Mcl-1, Bax and Bak in human uterine leiomyomas and myometrium during the menstrual cycle and after menopause. J Steroid Biochem Mol Biol 2002; 80: 77-83.

This is an open-access article distributed under the terms of the Creative Commons Attribution 4.0 International License (https:// creativecommons.org/licenses/by/4.0/), which permits unrestricted use, distribution, and reproduction in any medium, provided the original author and source are credited, a link to the CC License is provided, and changes - if any - are indicated. (SID_1) 